University of South Florida

DIGITAL COMMONS

Digital Commons @ University of

@ UNIVERSITY OF SOUTH FLORIDA

South Florida

Marine Science Faculty Publications

College of Marine Science

$12-7-2010$

\title{
Deglacial Abrupt Climate Change in the Atlantic Warm Pool: A Gulf of Mexico Perspective
}

\author{
Carlie Williams \\ University of South Florida St. Petersburg \\ Benjamin P. Flower \\ University of South Florida, bflower@marine.usf.edu \\ David W. Hastings \\ Eckerd College \\ Thomas P. Guilderson \\ Lawrence Livermore National Laboratory \\ Kelly A. Quinn \\ University of South Florida St. Petersburg
}

See next page for additional authors

Follow this and additional works at: https://digitalcommons.usf.edu/msc_facpub

Part of the Marine Biology Commons

\section{Scholar Commons Citation \\ Williams, Carlie; Flower, Benjamin P.; Hastings, David W.; Guilderson, Thomas P.; Quinn, Kelly A.; and Goddard, Ethan A., "Deglacial Abrupt Climate Change in the Atlantic Warm Pool: A Gulf of Mexico Perspective" (2010). Marine Science Faculty Publications. 166. \\ https://digitalcommons.usf.edu/msc_facpub/166}

This Article is brought to you for free and open access by the College of Marine Science at Digital Commons @ University of South Florida. It has been accepted for inclusion in Marine Science Faculty Publications by an authorized administrator of Digital Commons @ University of South Florida. For more information, please contact digitalcommons@usf.edu. 


\section{Authors}

Carlie Williams, Benjamin P. Flower, David W. Hastings, Thomas P. Guilderson, Kelly A. Quinn, and Ethan A. Goddard 


\title{
Deglacial abrupt climate change in the Atlantic Warm Pool: A Gulf of Mexico perspective
}

\author{
Carlie Williams, ${ }^{1}$ Benjamin P. Flower, ${ }^{1}$ David W. Hastings, ${ }^{2}$ Thomas P. Guilderson, ${ }^{3}$ \\ Kelly A. Quinn, ${ }^{1}$ and Ethan A. Goddard ${ }^{1}$ \\ Received 15 January 2010; revised 5 September 2010; accepted 21 September 2010; published 7 December 2010.
}

[1] During the last deglaciation, Greenland ice core and North Atlantic sediment records exhibit multiple abrupt climate events including the Younger Dryas cold episode (12.9-11.7 ka). However, evidence for the presence of the Younger Dryas in the Gulf of Mexico (GOM) and the relationship between GOM sea surface temperature (SST) and high-latitude climate change is less clear. We present new $\mathrm{Mg} / \mathrm{Ca}-\mathrm{SST}$ records from two varieties of the planktonic foraminifer Globigerinoides ruber (white and pink) to assess northern GOM SST history from approximately $18.4-10.8 \mathrm{ka}$. Thirty-five accelerator mass spectrometry (AMS) ${ }^{14} \mathrm{C}$ dates from Orca Basin core MD02-2550 provide excellent age control and document high sedimentation rates $(\sim 40 \mathrm{~cm} / \mathrm{kyr})$. G. ruber (white and pink) $\mathrm{Mg} / \mathrm{Ca}$-SST data exhibit increases $\left(\sim 4.6 \pm 0.6^{\circ} \mathrm{C}\right.$ and $\sim 2.2 \pm 0.5^{\circ} \mathrm{C}$, respectively) from at least $17.8-16.6 \mathrm{ka}$, with nearly decadal resolution that are early relative to the onset of the Bolling-Allerod interstadial. Moreover, G. ruber (white) SST decreases at $16.0-14.7 \mathrm{ka}\left(\sim 1.0 \pm 0.5^{\circ} \mathrm{C}\right)$ and $12.8-11.6 \mathrm{ka}$ $\left(\sim 2.4 \pm 0.6^{\circ} \mathrm{C}\right)$ correlate to the Oldest and Younger Dryas in Greenland and Cariaco Basin. The G. ruber (pink) SST record, which reflects differences in seasonality and/or depth habitat, is often not in phase with G. ruber (white) and closely resembles Antarctic air temperature records. Overall, it appears that Orca Basin SST records follow Antarctic air temperature early in the deglacial sequence and exhibit enhanced seasonality during Greenland stadials.

Citation: Williams, C., B. P. Flower, D. W. Hastings, T. P. Guilderson, K. A. Quinn, and E. A. Goddard (2010), Deglacial abrupt climate change in the Atlantic Warm Pool: A Gulf of Mexico perspective, Paleoceanography, 25, PA4221, doi:10.1029/2010PA001928.

\section{Introduction}

[2] Greenland ice core records indicate large and abrupt temperature variations of $15-20^{\circ} \mathrm{C}$ during the last deglaciation, based on $\delta^{18} \mathrm{O}_{\text {ice }}$ and $\delta^{15} \mathrm{~N}$ data. The Oldest Dryas $(\sim 16.9-14.7 \mathrm{ka})$ and Younger Dryas $(\sim 12.9-11.7 \mathrm{ka})$ were stadial events displayed in Greenland ice records with extremely negative $\delta^{18} \mathrm{O}_{\text {ice }}$ values suggesting near glacial temperatures [Björck et al., 1998; Rasmussen et al., 2006]. Following the Oldest Dryas was the abrupt onset of the Bolling-Allerod warm period ( 14.7-12.7 ka) marked by a $9 \pm 3^{\circ} \mathrm{C}$ increase in Greenland air temperature at $14.67 \mathrm{ka}$ [Björck et al., 1998; Severinghaus and Brook, 1999; Rasmussen et al., 2006].

[3] The Younger Dryas has also been identified in marine and terrestrial records and is most strongly expressed in the North Atlantic region [Broecker et al., 1988]. For example, North Atlantic SSTs, derived from foraminiferal assemblages

\footnotetext{
${ }^{1}$ College of Marine Science, University of South Florida, St. Petersburg, Florida, USA.

${ }^{2}$ Collegium of Natural Sciences, Eckerd College, St. Petersburg, Florida, USA.

${ }^{3}$ Center for Accelerator Mass Spectrometry, Lawrence Livermore National Laboratory, Livermore, California, USA.

Copyright 2010 by the American Geophysical Union. 0883-8305/10/2010PA001928
}

off the northern coast of Norway exhibit a $6-8^{\circ} \mathrm{C}$ decrease, suggesting increased dominance of Arctic Water [Ruddiman, 1977; Ebbesen and Hald, 2004]. Additionally, a sediment core off the Iberian margin at $37^{\circ} \mathrm{N}, 10^{\circ} \mathrm{W}$, displays a $5^{\circ} \mathrm{C}$ cooling based on alkenone temperature reconstructions and an increase in ice rafted debris [Bard et al., 2000]. Northern European lake sediments exhibit changes in pollen assemblages indicating a reduction in pine-birch forests and an expansion of open habitats [Björck et al., 1996; Brauer et al., 1999; Demske et al., 2005]. Sediments from Lake Madtjärn, Sweden display a reduction of tree pollen such as Betula (birch) and Pinus (pine) pollen and an increase in shrubs and herbs including Dryas octopetala, Juniperus and Artemisia [Björck et al., 1996; Brauer et al., 2008].

[4] Greenland and Antarctic ice core records are not in phase during the last deglacial period [Broecker, 1998; Stocker, 2000; Blunier and Brook, 2001; EPICA Community Members et al., 2006]. While Antarctic records display a warming trend from $\sim 19-14 \mathrm{ka}$, Greenland remains cold until a marked warming at the onset of the Bolling-Allerod at $14.67 \mathrm{ka}$. From 14.0-12.0 ka, Antarctic temperatures decrease during the Antarctic Cold Reversal, roughly coinciding with the Bolling-Allerod warm period [Blunier et al., 1997]. Antarctic temperatures increase again during the Younger Dryas at $12.5 \mathrm{ka}$ before stabilizing at the Younger Dryas termination $(11.7 \mathrm{ka})$. 


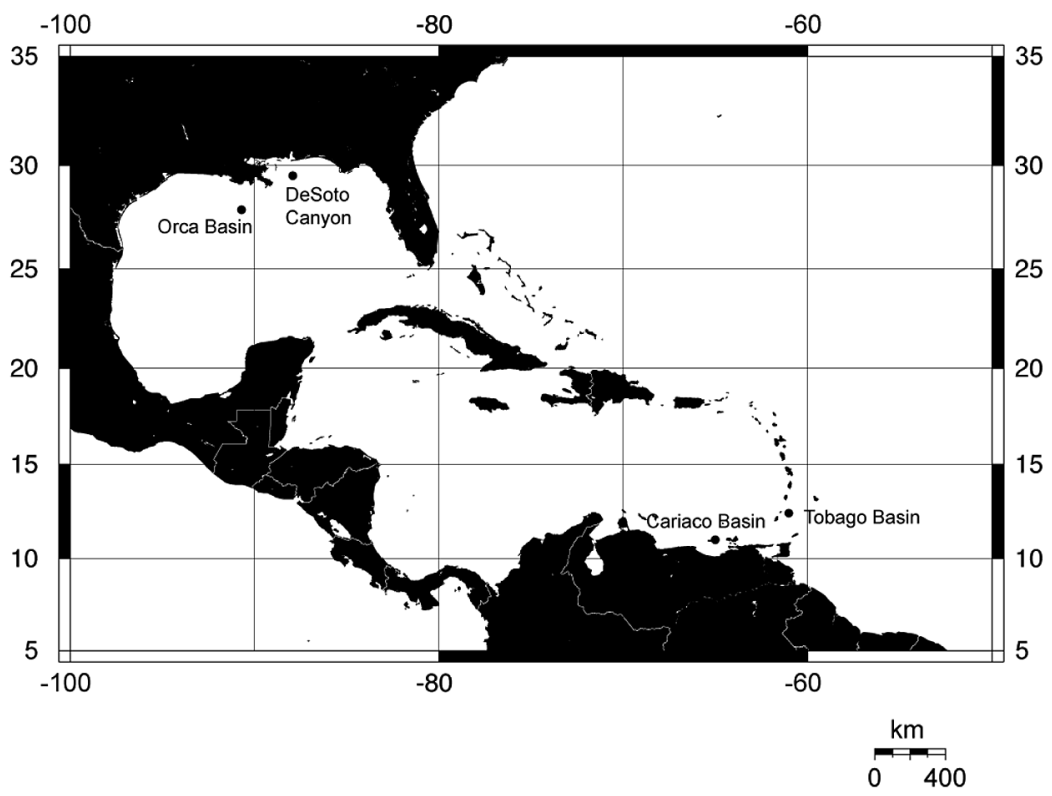

Figure 1. Location map of the Atlantic Warm Pool showing Orca Basin, DeSoto Canyon, Tobago Basin, and Cariaco Basin core sites. Source: Online Map Creation (http://aquarius.geomar.de/).

[5] In addition to ice core records, the Antarctic Cold Reversal is expressed in the Southern Hemisphere in SST and glacial advance records. A SST reconstruction off the coast of Chile exhibits a cool interval from 15.0 to $13.0 \mathrm{ka}$ during the Bolling-Allerod/Antarctic Cold Reversal and a rapid increase $\left(\sim 2.0^{\circ} \mathrm{C}\right)$ during the Younger Dryas [Lamy et al., 2004]. Furthermore, new evidence suggests that the Waiho Loop advance of the Franz Josef Glacier in New Zealand occurred during the Antarctic Cold Reversal, before the onset of the Younger Dryas [Barrows et al., 2007].

[6] This nearly antiphase correlation may be a result of asymmetric poleward heat transport [Broecker, 1998; Stocker, 2000]. Climate modeling studies indicate that the seesaw effect produces a warming in the South Atlantic and western tropical Atlantic during intervals of North Atlantic Deep Water (NADW) reduction. When NADW formation is reduced, models exhibit a decrease in cross-equatorial heat transport, producing tropical and subtropical warming due to excess heat build-up near the equator and in the Southern Hemisphere [Crowley, 1992; Manabe and Stouffer, 1997; Vellinga et al., 2002]. Thus, NADW reduction during cold stadials such as the Oldest Dryas and Younger Dryas may cause warming in the low-latitude Atlantic Ocean.

\section{Atlantic Warm Pool}

[7] Encompassing the Caribbean Sea and GOM, the Atlantic Warm Pool (AWP), is the second largest warm pool in the ocean. Developing during the late boreal spring and reaching SSTs greater than $28.5^{\circ} \mathrm{C}$ in the late summer, the AWP is an important source of both heat and moisture to the North American continent. Seasonal changes associated with the AWP also influence the North American Monsoon system as well as the development of tropical storms in the low-latitude western Atlantic Ocean region [Wang and Enfield, 2001].

[8] Proxy SST records from the Caribbean Sea indicate complex regional differences in deglacial SST. Alkenonederived SSTs from a sediment core in Tobago Basin (Figure 1), exhibit a $1.0^{\circ} \mathrm{C}$ warming during the Younger Dryas [Rühlemann et al., 1999]. In contrast, Cariaco Basin exhibits synchronous changes in $\mathrm{Mg} / \mathrm{Ca}-\mathrm{SST}$ s to Greenland ice core records with a $4^{\circ} \mathrm{C}$ decrease during the Younger Dryas [Lea et al., 2003]. However, Cariaco Basin SST may be decoupled from the regional signal because wind-driven upwelling influences the annual SST cycle [Muller-Karger et al., 2001].

[9] The GOM also appears to have a large degree of heterogeneity during the last deglaciation. The Younger Dryas has previously been identified in the GOM using $\delta^{18} \mathrm{O}_{\text {calcite }}\left(\delta^{18} \mathrm{O}_{\mathrm{C}}\right)$ and faunal assemblage data. Oxygen isotope data on $G$. ruber from Orca Basin exhibits positive $\delta^{18} \mathrm{O}_{\mathrm{C}}$ values of approximately $0 \%$ centered at about $12.0 \mathrm{ka}$, which are significantly greater than mean Holocene values of approximately $-1.5 \%$ [Leventer et al., 1982; Flower and Kennett, 1990; Flower et al., 2004]. Additionally, foraminiferal assemblage data suggest a SST decrease associated with the Younger Dryas [Kennett et al., 1985; Flower and Kennett, 1990]. However, both $\delta^{18} \mathrm{O}_{\mathrm{C}}$ and faunal assemblage data are also influenced by factors other than SST.

[10] A Mg/Ca-SST record, based on G. ruber (white) from Orca Basin (core EN32-PC6) exhibits SST increases during Oldest and Younger Dryas $\left(>1^{\circ} \mathrm{C}\right)$ plus rapid decrease of $\sim 1^{\circ} \mathrm{C}$ during the later part of the Younger Dryas (Figure 2). While warming in the Caribbean and GOM during Oldest Dryas stadial has been attributed to the retention of heat in the low latitudes due to a reduction 

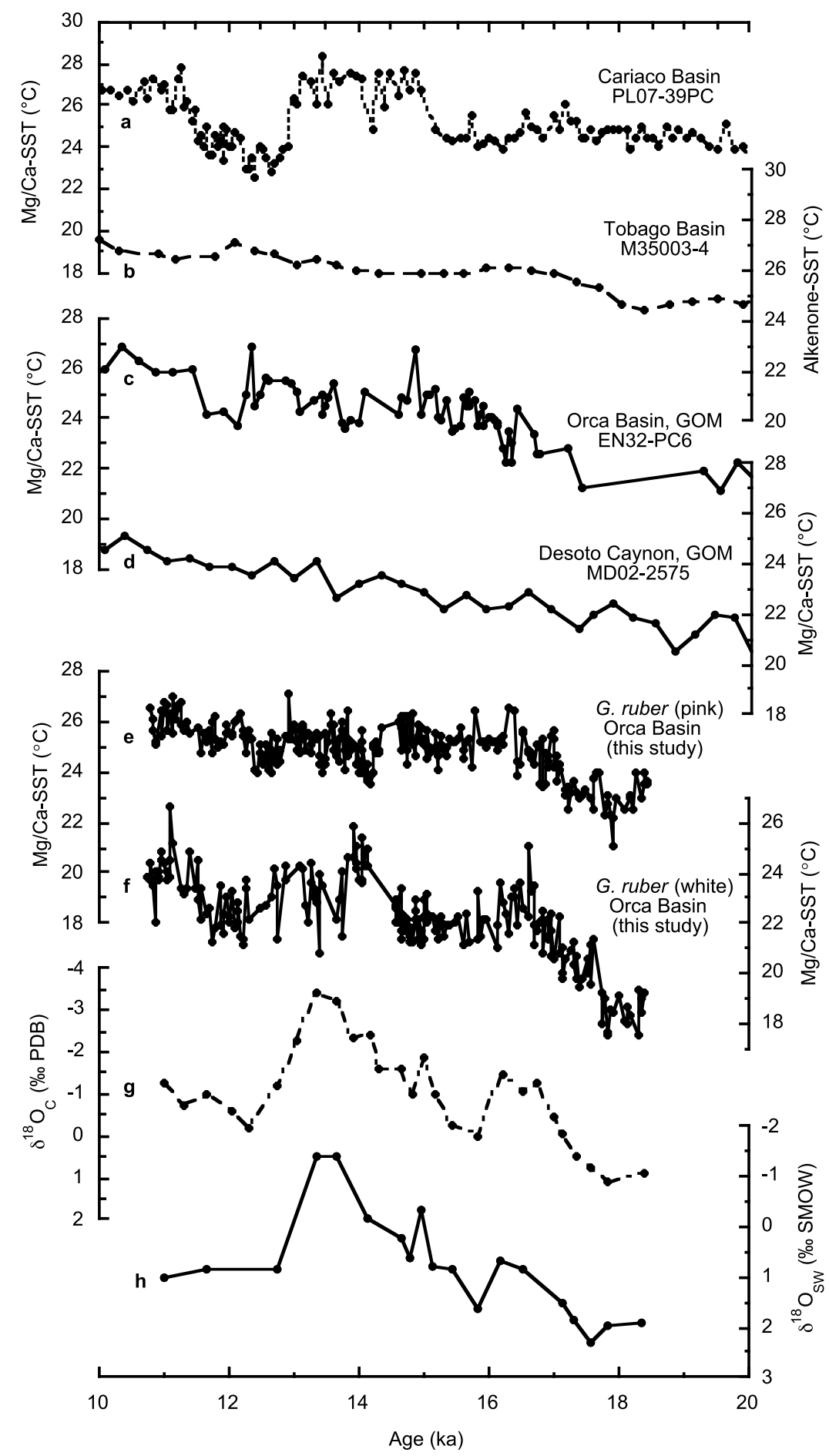

Figure 2. Comparison of previous AWP climate reconstructions including (a) Cariaco Basin G. ruber (white) $\mathrm{Mg} / \mathrm{Ca}-\mathrm{SST}$ [Lea et al., 2003]; (b) Tobago Basin alkenone-SST [Rühlemann et al., 1999]; (c) Orca Basin, GOM G. ruber (white) Mg/Ca-SST [Flower et al., 2004]; (d) DeSoto Canyon G. ruber (white) $\mathrm{Mg} / \mathrm{Ca}-\mathrm{SST}$ [Nürnberg et al., 2008; Ziegler et al., 2008]; (e) Orca Basin G. ruber (pink) $\mathrm{Mg} / \mathrm{Ca}-\mathrm{SST}$ (this study); (f) Orca Basin G. ruber (white) $\mathrm{Mg} / \mathrm{Ca}-\mathrm{SST}$ (this study); (g) G. ruber (white) $\delta^{18} \mathrm{O}_{\mathrm{C}}$ (this study); and (h) G. ruber (white) $\delta^{18} \mathrm{O}_{\mathrm{Sw}}$ (this study).

in thermohaline circulation (THC) [Rühlemann et al., 1999; Flower et al., 2004], the SST pattern during the Younger Dryas is equivocal and raises the possibility of additional forcing mechanisms. Moreover, low sample resolution and insufficient age control may have compromised the EN32-PC6 record. 
[11] In contrast, G. ruber (white) $\mathrm{Mg} / \mathrm{Ca}-\mathrm{SST}$ reconstructions from the DeSoto Canyon (core MD50-2575) in the northeastern GOM show modest SST variability during the Oldest and Younger Dryas [Nürnberg et al., 2008; Ziegler et al., 2008] (Figure 2). Indeed, the data suggest a monotonic increase of $\sim 3^{\circ} \mathrm{C}$ from approximately 19-11 ka. Nürnberg et al. [2008] attribute the modest SST change in DeSoto Canyon to the continued presence of a well-developed Loop Current in the northeastern GOM during the deglacial interval that warmed the northeastern GOM. Ziegler et al. [2008] use the $\mathrm{Mg} / \mathrm{Ca}-\mathrm{SST}$ record to support changes in the intertropical convergence zone (ITCZ) and the subsequent expansion of the northern front of the AWP, which yielded persistent summer conditions during Greenland stadials and enhanced seasonality during these events.

[12] Here we compare new and published data to help clarify the regional differences in GOM SST history. Resolving GOM SST will help differentiate potential forcing functions including solar insolation and ocean circulation changes. We present two new high-resolution $\mathrm{Mg} / \mathrm{Ca}$-SST records spanning the last deglaciation (18.4-10.8 ka) from Orca Basin in the northern GOM. With excellent radiocarbon age control, we evaluate the timing and magnitude of SST changes relative to known abrupt climate events, as well as the complications in interpreting climate reconstructions from the northern GOM.

\section{Core Location and Methods}

[13] Located in the northern GOM approximately $300 \mathrm{~km}$ from the Mississippi River delta, Orca Basin currently has an anoxic brine pool (salinity $>250 \mathrm{psu}$ ) that provides a laminated, nonbioturbated record of GOM paleoceanography (Figure 1). High sedimentation rates (approximately $40 \mathrm{~cm} / \mathrm{kyr}$ ) allow for high-resolution sampling at nearly decadal resolution and abundant aragonite pteropod tests suggest negligible carbonate dissolution throughout the core.

[14] Core MD02-2550 (9.09 m giant $25 \mathrm{~cm}^{2}$ Calypso gravity core), recovered from $2248 \mathrm{~m}$ water depth $\left(26^{\circ} 56.78^{\prime} \mathrm{N}, 9^{\circ} 20.75^{\prime} \mathrm{W}\right)$ by the R/V Marion Dufresne in 2002, was sampled every half centimeter from 311 to $466 \mathrm{~cm}$ and every $1 \mathrm{~cm}$ to $622 \mathrm{~cm}$. All samples were freeze-dried, wet sieved and washed over a $63 \mu \mathrm{m}$ mesh with deionized water. When available, approximately 30-40 individuals of the planktonic foraminiferal species $G$. ruber (white and pink varieties, separately) were picked from the 250-355 $\mu \mathrm{m}$ size fraction for elemental ratio and stable isotope analysis.

[15] Once picked, samples were sonicated in methanol for five seconds to remove fossil particles from inside the G. ruber tests, dried and weighed. Samples were split in half for elemental and isotopic analyses. The first half was pulverized for homogeneity and a 50-80 $\mu \mathrm{g}$ aliquot was analyzed on a ThermoFinnigan Delta Plus XL dual-inlet mass spectrometer with an attached Kiel III carbonate preparation device at the College of Marine Science, University of South Florida. Foraminiferal $\delta^{18} \mathrm{O}_{\mathrm{C}}$ data calibrated with standard NBS-19 are re- ported on the PDB scale. Long-term analytical precision based on $>1000$ NBS-19 standards is $\pm 0.06 \%$ for $\delta^{18} \mathrm{O}_{\mathrm{C}}$. The second half was lightly crushed between two glass plates and extensively cleaned for $\mathrm{Mg} / \mathrm{Ca}$ analyses [Barker et al., 2003]. The Cambridge cleaning process includes multiple trace metal clean water and methanol rinses to remove clays, an oxidizing treatment with a buffered peroxide solution to remove organic material and a weak acid leach to remove adsorbed particles. Samples were then dissolved in a weak 0.075 $\mathrm{N} \mathrm{HNO}_{3}$ solution and placed in a centrifuge for $5 \mathrm{~min}$ at $5000 \mathrm{rpm}$ to remove any remaining clays from the overlying solution. Last, a $400 \mu \mathrm{L}$ aliquot was diluted with $2 \% \mathrm{HNO}_{3}$ to a target calcium concentration of $25 \mathrm{ppm}$ and analyzed on an Agilent Technologies $7500 \mathrm{cx}$ inductively coupled plasma mass spectrometer (ICP-MS) located in the College of Marine Science at the University of South Florida.

[16] SST was calculated using fixed exponential calibration curves based on sediment trap data from the Sargasso Sea: $\mathrm{Mg} / \mathrm{Ca}=0.449^{0.09 * \mathrm{SST}}$ for $G$. ruber (white) and $\mathrm{Mg} / \mathrm{Ca}=0.381^{0.09 * \mathrm{SST}}$ for G. ruber (pink) [Anand et al., 2003]. This technique yields calcification temperatures with an accuracy of approximately $\pm 1.2^{\circ} \mathrm{C}$ [Anand et al., 2003]. Instrumental precision ( 1 standard deviation) for $\mathrm{Mg} / \mathrm{Ca}$ is $\pm 0.01 \mathrm{mmol} / \mathrm{mol}$, based on analyses of approximately 1500 reference standards, over the course of 16 runs. Average standard deviation of 38 replicate G. ruber (white) $\mathrm{Mg} / \mathrm{Ca}$ analyses ( $11 \%$ of total data set) is $\pm 0.077 \mathrm{mmol} / \mathrm{mol}$. Average standard deviation of 51 replicate pink G. ruber $\mathrm{Mg} / \mathrm{Ca}$ analyses $(12 \%$ of total data set) is $\pm 0.097 \mathrm{mmol} / \mathrm{mol}$.

[17] The G. ruber $\delta^{18} \mathrm{O}_{\mathrm{C}}$ record is affected by variations in calcification temperature and $\delta^{18} \mathrm{O}_{\text {seawater }}\left(\delta^{18} \mathrm{O}_{\mathrm{SW}}\right)$, which is dependent on ice volume and salinity. The $\delta^{18} \mathrm{O}_{\mathrm{SW}}$ was isolated by removing the isotopic effects of temperature with the independent $\mathrm{Mg} / \mathrm{Ca}-\mathrm{SST}$ proxy and applying the Orbulina universa high-light equation (SST $\left.\left({ }^{\circ} \mathrm{C}\right)=14.9-4.8\left(\delta^{18} \mathrm{O}_{\mathrm{C}}-\delta^{18} \mathrm{O}_{\mathrm{SW}}\right)\right)$ [Bemis et al., 1998], which is appropriate for G. ruber [Thunell et al., 1999]. A constant $0.27 \%$ was added to convert resulting $\delta^{18} \mathrm{O}_{\mathrm{Sw}}$ values to the Standard Mean Ocean Water (SMOW) scale. All data can be accessed at the NOAA/NCDC World Data Center at http://www.ncdc.noaa.gov/paleo/paleo.html.

\section{4. $\mathrm{Mg} / \mathrm{Ca}$ Data Generation}

[18] $\mathrm{Mg} / \mathrm{Ca}$ method development on the Agilent Technologies 7500cx ICP-MS, equipped with an ASX-500 autosampler, MicroMist concentric nebulizer and doublepass (Scott-type) quartz spray chamber, Peltier cooled to $2^{\circ}$, included determination of acquired isotopes, integration times, repetitions, peristaltic pump program, and optimal tuning parameters. A fully quantitative, isotope analysis acquisition mode was used, for which three central peak points were measured for each mass. Acquired isotopes and respective integration times are shown in Table 1. Five repetitions per sample were acquired to ensure reproducibility. Due to small sample volume, peristaltic pump conditions (timing and speed) were optimized to handle volumes ranging from $4.0 \mathrm{~mL}$ to $0.5 \mathrm{~mL}$. A $55 \mathrm{~s}$ rinse with $2 \% \mathrm{HNO}_{3}$ was used to reduce any sample-to- 
Table 1. Acquired Isotopes and Respective Dwell Times for Analysis on the ICP-MS

\begin{tabular}{llcc}
\hline Analyte & $\begin{array}{c}\text { Detection } \\
\text { Mode }\end{array}$ & $\begin{array}{c}\text { Integration Time } \\
\text { Per Point }^{\mathrm{a}}(\mathrm{s})\end{array}$ & $\begin{array}{c}\text { Mean Blank } \\
\text { (counts per second) }\end{array}$ \\
\hline${ }^{26} \mathrm{Mg}$ & Analog & 0.1 & 20,556 \\
${ }^{27} \mathrm{Al}$ & Analog & 0.4 & 22,028 \\
${ }^{43} \mathrm{Ca}$ & Analog & 0.1 & 36,638 \\
${ }^{55} \mathrm{Mn}$ & Analog & 0.1 & 24,653 \\
\hline
\end{tabular}

${ }^{\mathrm{a}}$ Each of the five replicates includes 1000 scans through all acquired masses. Dwell time equals integration time/1000.

standard contamination. Prior to each run, a $100 \mathrm{ppb} \mathrm{Ca}$ solution was run for $30 \mathrm{~min}$ for cone conditioning. The ICP-MS was then tuned for low $(<2 \%)$ oxides and doubly charged ions as well as low relative standard deviations (RSDs).

[19] Multiple gravimetric standards were used to ensure optimal accuracy and precision. As high Ca concentrations may cause instrument drift and affect $\mathrm{Mg} / \mathrm{Ca}$ ratios, a series of experimental runs was performed to establish the potential calcium concentration effect on $\mathrm{Mg} / \mathrm{Ca}$ ratios and determine an ideal $\mathrm{Ca}$ concentration for sample dilution. Ten dilutions of four individual solutions with varying $\mathrm{Mg} / \mathrm{Ca}$ values, ranging from 2.1 to $8.2 \mathrm{mmol} / \mathrm{mol}$ were analyzed to determine an ideal $\mathrm{Ca}$ concentration range for which there was no change in $\mathrm{Mg} / \mathrm{Ca}$. Similar runs were repeated to ensure consistency. Although experimental run results showed insignificant differences between varying $\mathrm{Ca}$ concentrations and $\mathrm{Mg} / \mathrm{Ca}$ ratios, five serial dilutions of three $\mathrm{Mg} / \mathrm{Ca}$ ratio standards were analyzed before and after all sample analyses during each run.

[20] The serial dilutions and a powdered $\mathrm{CaCO}_{3}$ standard (ECRM-751) were analyzed multiple times per run to monitor to the calcium concentration effect and allow for interlaboratory comparison in accordance with [Greaves et al., 2008]. A reference solution with an ECRM-751 corrected $\mathrm{Mg} / \mathrm{Ca}$ ratio was alternated with all standards and samples to further calibrate and correct for instrumental drift [Schrag, 1999]. Five calibration standards for $\mathrm{Mg}$ and $\mathrm{Ca}$ and five for $\mathrm{Mn}$ and $\mathrm{Al}$ were analyzed in the beginning of each run to calibrate samples from count per second measurements to concentration.

\section{Determination of $\mathrm{Mg} / \mathrm{Ca}$ Data Quality}

[21] To assess $\mathrm{Mg} / \mathrm{Ca}$ data quality, $\mathrm{Al} / \mathrm{Ca}, \mathrm{Mn} / \mathrm{Ca}$ and weight per foraminifer measurements were used to monitor clay removal, potential $\mathrm{Mn}-\mathrm{Fe}$ oxide effects and the preferential removal of $\mathrm{Mg}$ due to postdepositional dissolution, respectively. $\mathrm{Mg} / \mathrm{Ca}-\mathrm{SST}$ records from various depositional environments suggest no universal $\mathrm{Al} / \mathrm{Ca}$ threshold value should be applied to all depositional environments [Lea et al., 2005] and previous studies in Orca Basin have not applied $\mathrm{Al} / \mathrm{Ca}$ thresholds to monitor foraminiferal clay removal (see auxiliary material). ${ }^{1}$ However, for a

\footnotetext{
${ }^{1}$ Auxiliary materials are available in the HTML. doi:10.1029/ 2010PA001928.
}

conservative interpretation of the $\mathrm{Mg} / \mathrm{Ca}-\mathrm{SST}$ record, data with $\mathrm{Al} / \mathrm{Ca}$ ratios greater than $200 \mu \mathrm{mol} / \mathrm{mol}$ were eliminated (approximately $7 \%$ and $13 \%$ of G. ruber samples (white and pink, respectively)) from the plots as their $\mathrm{Mg} / \mathrm{Ca}$ values might be influenced by excess $\mathrm{Mg}$ from insufficient clay removal. Mean relative standard deviations (RSDs) for $\mathrm{Al} / \mathrm{Ca}$ and $\mathrm{Mn} / \mathrm{Ca}$ data based on analyses of 84 ECRM-752 standards are $6 \%$ and $0.3 \%$. There is no correlation between $\mathrm{Al} / \mathrm{Ca}$ and $\mathrm{Mg} / \mathrm{Ca}$ ratios (G. ruber (white): $\mathrm{r}^{2}=$ 0.06; G. ruber (pink): $\mathrm{r}^{2}=0.02$ ) (Figures $\mathrm{S} 1$ and $\mathrm{S} 2$ ) or between $\mathrm{Mn} / \mathrm{Ca}$ and $\mathrm{Mg} / \mathrm{Ca}$ ratios (G. ruber (white): $\mathrm{r}^{2}=$ 0.02; G. ruber (pink): $\mathrm{r}^{2}=0.06$ ) (Figures S3 and S4). Weight per foraminifer values are relatively constant downcore at $13.49 \pm 2.1 \mu \mathrm{g}$ and do not correlate with $\mathrm{Mg} / \mathrm{Ca}$ data (G. ruber (white): $\mathrm{r}^{2}=0.05 ;$ G. ruber (pink): $\mathrm{r}^{2}=0.04$ ) (Figure S5).

\section{Age Model}

[22] Thirty-five accelerator mass spectrometry (AMS) ${ }^{14} \mathrm{C}$ dates, between 308 and $650 \mathrm{~cm}$, from monospecific $G$. ruber (white and pink varieties) provide excellent chronological control (Table S1). Raw radiocarbon ages were calibrated to calendar years using Calib 6.0, which applies the most recent radiocarbon to calendar age calibration (Marine09), and uses an assumed constant reservoir age correction of 405 years [Reimer et al., 2009].

[23] Although German pine chronologies and radiocarbon dated foraminifera from Cariaco Basin suggest that the lowlatitude western Atlantic surface ocean reservoir age decreased at the onset of the Younger Dryas [Kromer et al., 2004; Muscheler et al., 2008] and possibly the during the

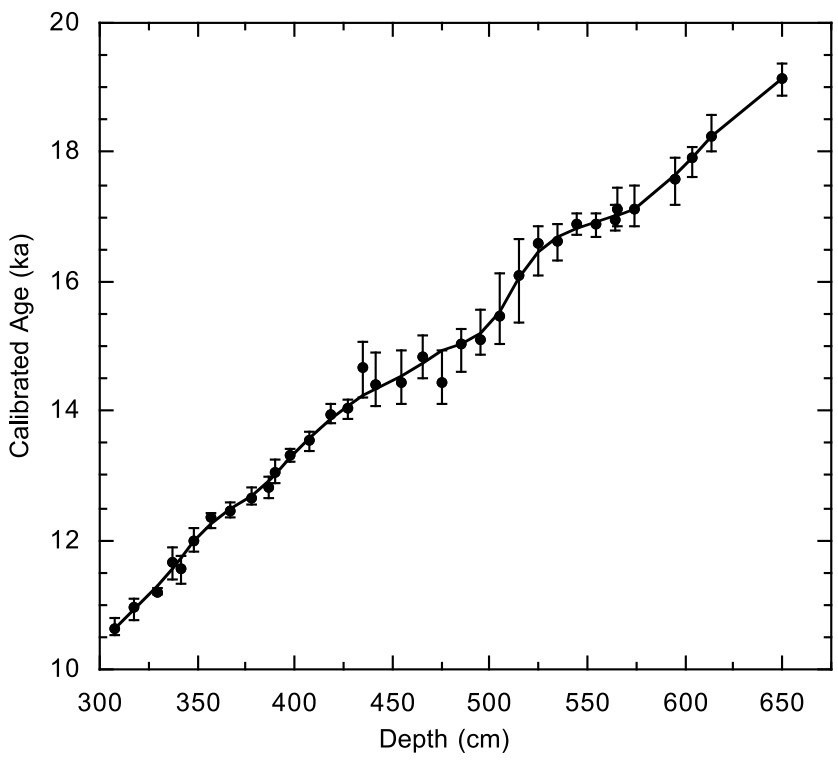

Figure 3. The age model for core MD02-2550 is based on 35 radiocarbon dates from monospecific planktonic foraminifera ( $G$. ruber). Error bars represent a 2 standard deviation error in calibration from radiocarbon to calendar years. Larger error bars from $\sim 16.5-14.5$ ka reflect a plateau in the radiocarbon to calendar year calibration. 
Oldest Dryas, varying reservoir age corrections are currently unavailable. However, we note that a reservoir age decrease to less than 200 years at the onset of the Younger Dryas would increase calendar ages by a similar amount from approximately $12.9-12.5$ ka [Kromer et al., 2004].

[24] Core depth was converted to calendar age by applying a weighted curve fit with a $15 \%$ smoothing factor (Figure 3). Error bars represent 2-sigma error in calibration from radiocarbon to calendar years. Mean accumulation rate is $40 \mathrm{~cm} / \mathrm{kyr}$. Half centimeter sample resolution between $311 \mathrm{~cm}$ and $466 \mathrm{~cm}$ yields a mean temporal resolution of $\sim 14$ years/sample, while $1 \mathrm{~cm}$ sample resolution from 466 to $621 \mathrm{~cm}$ is $\sim 24$ years/sample.

[25] Additionally, new age models based on the Marine09 calibration data set were created for all other records compared in this study including a ${ }^{231} \mathrm{~Pa} /{ }^{232} \mathrm{Th}$ record from the Bermuda Rise [McManus et al., 2004], and SST records from Cariaco Basin [Lea et al., 2003], Tobago Basin [Rühlemann et al., 1999], and previously published Gulf of Mexico studies [Flower et al., 2004; Nürnberg et al., 2008; Ziegler et al., 2008] to ensure a consistent age comparison to the new GOM records. Published ${ }^{14} \mathrm{C}$ ages were recalibrated and best fit lines were used to interpolate calendar age throughout each record (Figures S8, S9, S10, S11, and S12 and Tables S2, S3, S4, S5, and S6).

\section{Effects of Salinity on GOM SST}

[26] $\mathrm{Mg} / \mathrm{Ca}$-SST in the northern GOM may have been affected by several factors. Previous research based on foraminifera from laboratory culturing and sediment trap studies suggests that large changes in salinity may affect $\mathrm{Mg} / \mathrm{Ca}-\mathrm{SST}$ calibrations. Culturing studies of Globigerinoides sacculifer showed that SST dominated the $\mathrm{Mg} / \mathrm{Ca}$ signal except during large changes in salinity $(>10 \mathrm{psu})$ [Nürnberg et al., 1996]. A 10 psu increase in salinity also increased $\mathrm{Mg}$ concentrations by $110 \%$, equivalent to a $\sim 8^{\circ} \mathrm{C}$ change. Minor salinity changes $(<3 \mathrm{psu})$ showed no change in foraminiferal $\mathrm{Mg}$ concentrations. Another study using cultured Globigerina bulloides and Orbulina universa displayed elevated $\mathrm{Mg} / \mathrm{Ca}$ ratios with increasing salinity. Specifically, a $\mathrm{Mg} / \mathrm{Ca}$ ratio increase of $4 \%$ is seen for a $1 \mathrm{psu}$ increase which is equivalent to a $\sim 0.5^{\circ} \mathrm{C}$ change [Lea et al., 1999].

[27] Recent Mediterranean Sea sediment trap data show large increases in $\mathrm{Mg} / \mathrm{Ca}$ values only when foraminifera are living in high-salinity environments ( $>36.5 \mathrm{psu})$. However, there is no evidence that $\mathrm{Mg} / \mathrm{Ca}$ ratios are affected in salinities lower than 36.5 psu [Ferguson et al., 2008]. As modern annual mean GOM salinity is 35.5 psu [Levitus, 2003], the salinity affect on $\mathrm{Mg} / \mathrm{Ca}-\mathrm{SST}$ is likely minimal.

[28] Foraminiferal $\delta^{18} \mathrm{O}_{\mathrm{C}}$ and $\delta^{18} \mathrm{O}_{\mathrm{Sw}}$ data from G. ruber (white) from Orca Basin (Figure 2) suggest meltwater from the Laurentide Ice Sheet (LIS) for the majority of the last deglaciation. A previous study based on GOM $\delta^{18} \mathrm{O}_{\mathrm{SW}}$ and estimated LIS meltwater end-member compositions ( -25 to $-35 \%$ ) produced a $2-4$ psu salinity change [Flower et al., 2004], which could have increased SSTs by up to $2^{\circ} \mathrm{C}$, according to the relationship found by Lea et al. [1999]. Results from Nürnberg et al. [1996] and Ferguson et al.
[2008] would imply little to no SST change. However, published and new data from Orca Basin exhibit no correlation between $\mathrm{Mg} / \mathrm{Ca}$ values and salinity. For example, millennial-scale $\delta^{18} \mathrm{O}_{\mathrm{SW}}$ minima do not correspond to SST minima. Finally, our largest and sharpest increase in $\delta^{18} \mathrm{O}_{\mathrm{SW}}(\sim 2 \%)$ at approximately $12.9-11.7 \mathrm{ka}$ is not accompanied by a SST warming in either G. ruber (white or pink).

[29] Orca Basin SST reconstructions may also have been influenced by LIS meltwater. We examine the potential effect of meltwater on SST using an inferred 2-4 psu salinity change, calculated with a $\delta^{18} \mathrm{O}_{\text {ice }}$ LIS end-member value of -25 to $-35 \%$ [Flower et al., 2004]. A simple box model indicates that a $2-4$ psu salinity decrease requires a 5.6-11.3\% increase in Mississippi River water to the northern GOM. Modern Mississippi River temperatures (at Baton Rouge, LA) range annually from approximately $32^{\circ} \mathrm{C}$ in summer months to $\sim 7^{\circ} \mathrm{C}$ during the winter [Shiller, 1997]; however, the temperature of deglacial LIS meltwater is unknown. As maximum melting likely occurred during summer and spring months, it is possible that ambient air temperatures warmed Mississippi River waters as they flowed south. If deglacial Mississippi River input increased by $11.3 \%$, water temperatures must have decreased to at least $7.5^{\circ} \mathrm{C}$ to cool the GOM by $1^{\circ} \mathrm{C}$. However, a more moderate increase of $5.6 \%$ requires a temperature change of $\sim 16.5^{\circ} \mathrm{C}$ to decrease GOM SST by $1^{\circ} \mathrm{C}$. Because we have no accurate means to correct the $\mathrm{Mg} / \mathrm{Ca}-\mathrm{SST}$ for a possible direct meltwater cooling, we present our data with the caveat that Orca Basin SSTs may be affected by cold meltwater during episodes of meltwater input to the GOM (ca. 16-13 ka).

[30] In addition to a direct effect from LIS meltwater, it is possible that surface dwelling foraminifera such as G. ruber may have shifted to a greater depth or different season to avoid a low-salinity mixed layer and subsequently calcified in cooler waters not representative of surface conditions. An interval lacking foraminifers in core MD02-2550 may be due to a faunal response to a change in environmental conditions such as enhanced meltwater input. However, salinity estimates suggest GOM surface conditions were still habitable for G. ruber, given its wide salinity tolerances [Bé, 1959; Bijma et al., 1990]. Furthermore, migration to greater depths would produce cooler temperatures during large meltwater episodes, which is not seen in our data (Figure 2).

[31] Foraminiferal faunal data provide some support for a significant response to deglacial meltwater input. A distinct increase in percent $G$. ruber is recorded during the main meltwater spike based on $\delta^{18} \mathrm{O}_{\mathrm{C}}$ from Orca Basin core EN32PC6, which is interpreted as a response to lower salinities [Kennett et al., 1985]. However, there is no faunal evidence for direct cooling by LIS meltwater. Globorotalia inflata, a cold-water species in the GOM, exhibits higher-percent frequency and flux during the glacial interval than the meltwater spike [Kennett et al., 1985; Flower and Kennett, 1990]. Conversely, the warm-water species Neogloboquadrina dutertrei exhibits increasing frequency and flux across the meltwater spike. Similarly, factor analysis of the foraminiferal assemblages over time indicate cool conditions prior to the meltwater spike, warmer SSTs during the meltwater 
spike, and a brief return to near-glacial conditions near the beginning of the Younger Dryas [Kennett et al., 1985]. These trends are inconsistent with a significant direct effect of LIS meltwater on SST. However, an indirect effect in which foraminifera altered their preferred depth and/or seasonal habitat is still possible. Changes in depth or seasonal preferences over time may also affect the $G$. ruber SST records, but are very difficult to test down core.

\section{Interpretation of $G$. ruber (white and pink) $\mathrm{Mg} /$ Ca-SST}

[32] G. ruber (white and pink) are tropical to subtropical surface dwelling spinose foraminifera that are constrained to the surface mixed layer by photoautotrophic dinoflagellate symbionts. Modern depth preferences of planktic foraminifera such as $G$. ruber have been studied extensively in the Sargasso Sea, although little work has focused on the GOM. Monthly plankton tows from the Sargasso Sea showed that white and pink varieties were most abundant in the top $10 \mathrm{~m}$ [Tolderlund and Bé, 1971]. A single tow in the western GOM revealed that the white variety is present from 0 to $50 \mathrm{~m}$ water depth, while the less abundant G. ruber (pink) is found slightly deeper $(25-50 \mathrm{~m})$ [Bé, 1982].

[33] Sediment trap data from twenty global sites illustrate the large surface temperature range of $G$. ruber (white) of $\sim 10-31^{\circ} \mathrm{C}$, with optimum SSTs at $22-31^{\circ} \mathrm{C}$. The pink variety has a much smaller range of $16-30^{\circ} \mathrm{C}$ with ideal SSTs at 23-30 ${ }^{\circ} \mathrm{C}$ [Žarić et al., 2005]. Plankton tow data from the Sargasso Sea reveal that $G$. ruber (white and pink) are commonly found in SSTs ranging from 18 to $26^{\circ} \mathrm{C}$, with highest concentrations seen at $23-27^{\circ} \mathrm{C}$. The pink variety is also found at warmer temperatures up to $28^{\circ} \mathrm{C}$ [Bé and Hamlin, 1967].

[34] Seasonal preferences of G. ruber (white and pink) also appear to be different. Although both varieties exhibit their highest abundances during the summer months in the Sargasso Sea, G. ruber (pink) is rare and often absent in winter months (January-March) [Bé, 1960; Tolderlund and Bé, 1971; Williams et al., 1981]. A recent sediment trap study supports this finding in the GOM (January-December 2008) [Tedesco et al., 2009]. Indeed, G. ruber (pink) exhibits low flux in winter months. However, G. ruber (white) fluxes are lower throughout the year than expected based on core top and late Holocene sediments (2\% versus $20-30 \%)$ [Bé and Hamlin, 1967; Kennett et al., 1985; LoDico et al., 2006; Tedesco et al., 2009]. Possible explanations for low $G$. ruber (white) flux contributions may include the near proximity of the sediment trap to the Mississippi River outflow region ( $<150$ miles). Additionally, surface salinity values as low as 31.3 psu may force $G$. ruber to change its preferred depth or season.

\section{GOM Climate Based on G. ruber (white) $\mathrm{Mg} / \mathrm{Ca}-\mathrm{SST}$}

[35] Because of its upper mixed layer habitat, G. ruber (white) is widely used as an SST proxy in the low-latitude Atlantic [Keigwin, 1996; Lea et al., 2003; Flower et al., 2004; Schmidt et al., 2004; LoDico et al., 2006; Lund and
Curry, 2006; Richey et al., 2007; Nürnberg et al., 2008; Ziegler et al., 2008; Richey et al., 2009]. A separate data set that includes core top $G$. ruber (white and pink) stable isotope and $\mathrm{Mg} / \mathrm{Ca}$ data from different size fractions demonstrates that the two species-specific equations for G. ruber (white and pink) (with fixed exponential constants) [Anand et al., 2003] represent an internally consistent set of calibration equations appropriate for the GOM [Richey et al., 2008]. GOM zero age core top material yields a G. ruber (white) $\mathrm{Mg} / \mathrm{Ca}$ value of $4.43 \mathrm{mmol} / \mathrm{mol}$ which is equivalent to a modern mean annual temperature of $25.4^{\circ} \mathrm{C}$ [Richey et al., 2007, 2009].

[36] During the last deglaciation, G. ruber (white) $\mathrm{Mg} / \mathrm{Ca}-$ derived SST exhibits an early deglaciation to early Holocene warming of $5.6 \pm 0.6^{\circ} \mathrm{C}$ (mean $=18.4^{\circ} \mathrm{C}$ from 18.4 to $17.8 \mathrm{ka}$; mean $=24.0^{\circ} \mathrm{C}$ from 10.8 to $11.5 \mathrm{ka}$ ) (Figure 4 ). A stepwise SST increase $\left(4.6 \pm 0.6^{\circ} \mathrm{C}\right)$ is seen from approximately $17.8-16.6 \mathrm{ka}$, followed by a sustained $1.0 \pm 0.5^{\circ} \mathrm{C}$ cooling from 16.0 to $14.7 \mathrm{ka}$ (based on mean SST difference between 16.7 and $16.4 \mathrm{ka}$ and $16.0-14.7 \mathrm{ka}$ intervals). From 14.7 to $12.9 \mathrm{ka}$, warm SSTs dominate with an increase in SST $\left(2.7 \pm 0.6^{\circ} \mathrm{C}\right)$, peaking at $13.9 \mathrm{ka}$. Additionally, multiple short cool periods are superimposed $\left(>1.0^{\circ} \mathrm{C}\right.$ SST decreases; $<200$ years $)$. Last, from 12.8 to $11.6 \mathrm{ka}$, SSTs decrease by approximately $2.4 \pm 0.6^{\circ} \mathrm{C}$ (based on a mean SST difference between 14.0 and 13.8 $\mathrm{ka}$ and 12.2-11.7 ka), followed by an increase to approximately $24.0^{\circ} \mathrm{C}$.

[37] In contrast to a previous Orca Basin study (core EN32-PC6) [Flower et al., 2004], our new higher-resolution SST record exhibits a larger early deglacial warming (nearly $5^{\circ} \mathrm{C}$, compared to $3^{\circ} \mathrm{C}$ in core EN32-PC6) (Figure 2). However, this interval is only constrained by six data points in the EN32-PC6 record and consequently may have underestimated SST changes. Differences between the G. ruber (white) $\mathrm{Mg} / \mathrm{Ca}-\mathrm{SST}$ records from Orca Basin are likely due to low-resolution sampling bias in both $\mathrm{Mg} / \mathrm{Ca}$ and ${ }^{14} \mathrm{C}$ records of the EN32-PC6 core.

[38] The new G. ruber (white) $\mathrm{Mg} / \mathrm{Ca}-\mathrm{SST}$ record exhibits similarities to DeSoto Canyon and Tobago Basin SST during the early deglacial period (18.4-16.6 ka) (Figure 2). When compared on a common calibrated age scale, each record shows an early temperature increase from 17.8 to $16.6 \mathrm{ka}$; although DeSoto Canyon $\mathrm{Mg} / \mathrm{Ca}-\mathrm{SST}$ and Tobago Basin alkenone-SST exhibit smaller SST increases [Rühlemann et al., 1999; Nürnberg et al., 2008].

[39] Similarities between the Gulf of Mexico and Tobago Basin SST [Rühlemann et al., 1999], local insolation [Laskar et al., 2004], the ${ }^{231} \mathrm{~Pa} /{ }^{230} \mathrm{Th}$ proxy for $\mathrm{THC}$ strength [McManus et al., 2004] and Antarctic EDML $\delta^{18} \mathrm{O}_{\text {ice }}$ [EPICA Community Members et al., 2006] records suggest that early deglacial warming may be caused by a combination of local insolation increase and reduction in cross-equatorial heat transport (Figures 2 and 4). As climate modeling studies indicate [Crowley, 1992; Manabe and Stouffer, 1997; Vellinga et al., 2002], a reduction in NADW should produce low-latitude and Southern Hemisphere SST increases. The ${ }^{231} \mathrm{~Pa} /{ }^{230} \mathrm{Th}$ ratio, dependent on the rate of removal from the water column (Pa has a much longer residence time in the North Atlantic) can be 


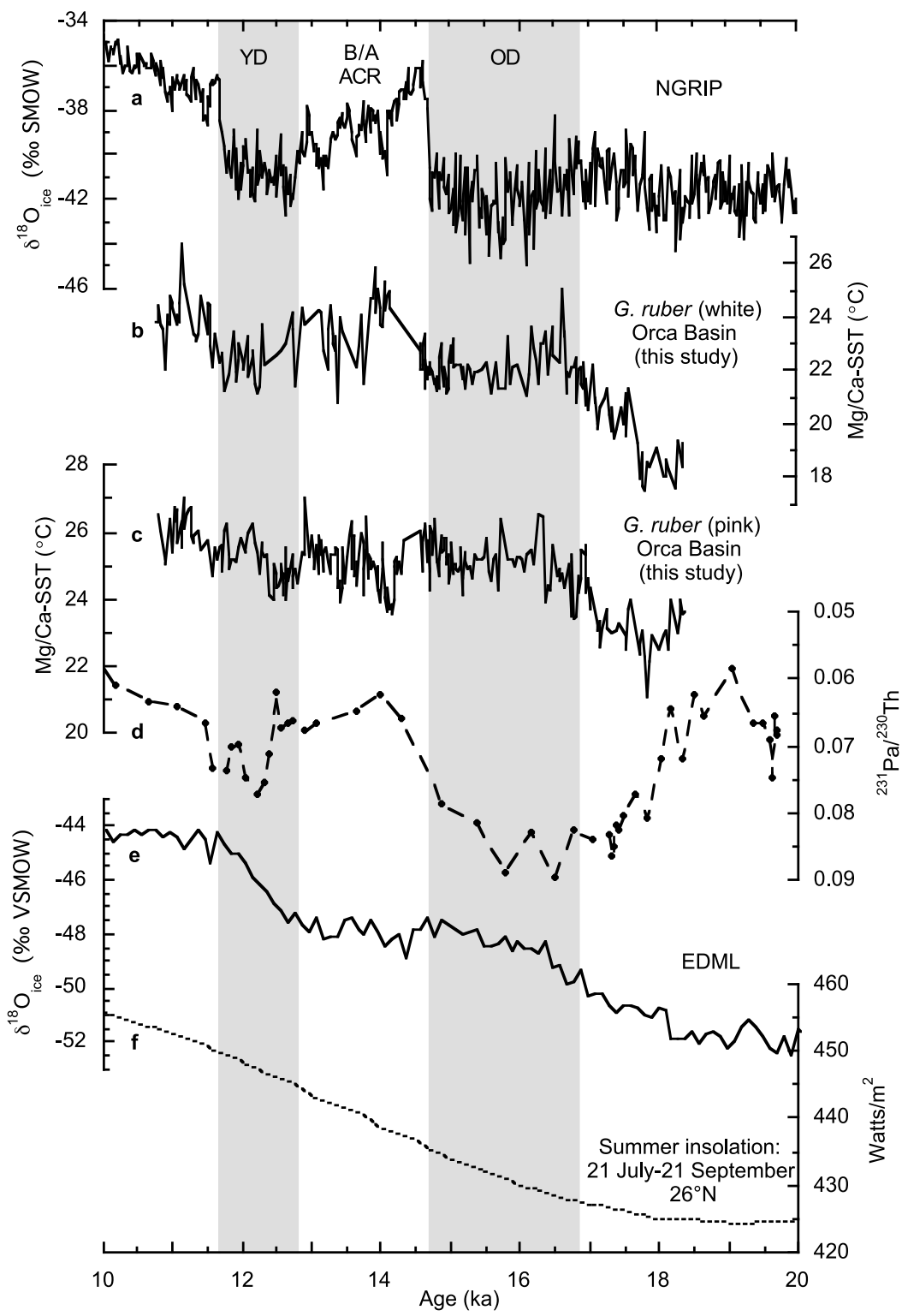

Figure 4. Comparison of (a) Greenland (NGRIP) $\delta^{18} \mathrm{O}_{\text {ice }}$ [Rasmussen et al., 2006], (b) G. ruber (white) $\mathrm{Mg} / \mathrm{Ca}-\mathrm{SST}$ (this study), (c) G. ruber (pink) $\mathrm{Mg} / \mathrm{Ca}-\mathrm{SST}$ (this study), (d) ${ }^{231} \mathrm{~Pa} /{ }^{232} \mathrm{Th} \mathrm{THC}[$ McManus et al., 2004], (e) Antarctic (EDML) $\delta^{18} \mathrm{O}_{\text {ice }}$ [EPICA Community Members et al., 2006], and (f) local summer insolation $\left(26^{\circ} \mathrm{N}\right)$ [Laskar et al., 2004]. Shaded bars denote the Oldest Dryas (OD), BollingAllerod (B/A), Antarctic Cold Reversal (ACR), and Younger Dryas (YD).

used as a proxy for thermohaline circulation (THC) strength and exhibits two intervals of decreased NADW formation during the last deglaciation. While the Younger Dryas coincides with a decrease in NADW strength, an earlier interval may have been a complete shutdown in THC [McManus et al., 2004]. However, several studies suggest elevated $\mathrm{Pa} / \mathrm{Th}$ values may also be due to enhanced $\mathrm{Pa}$ scavenging by biogenic silica and that the relationship between $\mathrm{Pa} / \mathrm{Th}$ values may not be linearly correlated to NADW strength [Keigwin and Boyle, 2008]. Nevertheless, early warming in Orca Basin, DeSoto
Canyon, and Tobago Basin suggests that a decrease THC strength, amplified by a local insolation increase is responsible for a low-latitude heat buildup.

[40] There is some evidence for tropical heat buildup during a second interval of THC reduction, the Younger Dryas (12.9-11.7 ka) [Rühlemann et al., 1999]. While our new $G$. ruber (pink) SST record (discussed later) exhibits an increase of about $1.4^{\circ} \mathrm{C}$, the G. ruber (white) SST record reveals a large decrease of approximately $2.4^{\circ} \mathrm{C}$. Moreover, a rejuvenation of NADW should have the opposite effect on SSTs, causing an increase in heat transport out of the 
Southern Hemisphere and low-latitude Atlantic Ocean. However, at the onset of the Bolling ( 14.7 ka) when THC strengthens, there is no SST decrease in the $G$. ruber (white), but rather a large increase of $\sim 2.7^{\circ} \mathrm{C}$. It is possible that the response of the low-latitude Atlantic to NADW variability is driven by the magnitude of THC change. If the NADW decrease during the Younger Dryas was smaller than previous NADW changes as indicated by $\mathrm{Pa} / \mathrm{Th}$ values, the low-latitude heat buildup may not have extended as far north as the GOM.

[41] During the late deglacial interval (16.6-10.8 ka), G. ruber (white) $\mathrm{Mg} / \mathrm{Ca}-\mathrm{SST}$ records from Cariaco Basin and the Orca Basin exhibit similar patterns that correspond to the Oldest Dryas, Bolling-Allerod and Younger Dryas inferred from Greenland ice core records. While Cariaco Basin SST displays a $1.5^{\circ} \mathrm{C}$ SST reduction from 16.6 to $14.7 \mathrm{ka}$ [Lea et al., 2003] during the Oldest Dryas, Orca Basin SST exhibits a similar cooling of $1.0^{\circ} \mathrm{C}$ at 16.0-14.7 ka (Figure 2). Both records exhibit a SST increase at the onset of the Bolling-Allerod warm period $(\sim 14.7 \mathrm{ka})$. After the initial rapid increase, Cariaco Basin maintains a relatively constant temperature until the Younger Dryas while Orca Basin G. ruber (white) SST peaks at the onset of the Bolling-Allerod and slowly cools until the rapid cooling during the Younger Dryas, similar to Greenland $\delta^{18} \mathrm{O}_{\text {ice. }}$.

[42] Higher-frequency cool periods are evident in the Orca Basin SST record, but radiocarbon measurement error and calibration prevent such short intervals to be precisely correlated. However, three prominent SST decreases during the Bolling-Allerod interval (14.0-13.9, 13.8-13.5, and 13.4-13.1 ka) may coincide with events seen in the Greenland ice core records such as the Older Dryas, $(14.1-13.9 \mathrm{ka})$, an unnamed event $(13.8-13.5 \mathrm{ka})$, and the IntraAllerod Cold Period (13.4-12.8 ka), which would suggest that centennial-scale climate change seen in Greenland ice core records is not limited to the North Atlantic region but also is manifested in low-latitude SST. However, ${ }^{14} \mathrm{C}$ calibration error of approximately 100-200 years likely prohibits the identification of such rapid SST changes.

[43] The Younger Dryas event is also manifested in Cariaco Basin and Orca Basin as a G. ruber (white) SST decrease $\left(\sim 4.0^{\circ} \mathrm{C}\right.$ and $\sim 2.4^{\circ} \mathrm{C}$, respectively) from approximately $12.8-11.6 \mathrm{ka}$. The SST change in Cariaco Basin is nearly double that of Orca Basin at the onset of the Younger Dryas and significantly greater than the Oldest Dryas in the same core [Lea et al., 2003]. In contrast, G. ruber (white) Orca Basin SST exhibits a similar magnitude cooling for both events. While the onset is very abrupt (transition $<300$ years) in Cariaco Basin, the low numbers of $G$. ruber individuals and consequent low temporal resolution in core MD02-2550 prevent us from accurately determining the rapidity of initial Orca Basin cooling during the Younger Dryas. The lack of SST change in DeSoto Canyon is attributed to the presence of a welldeveloped Loop Current during the deglacial sequence [Nürnberg et al., 2008], which likely created a distinct climate region in the eastern GOM controlled by Loop Current dynamics and masked abrupt climate events such as the Younger Dryas that are seen in the Orca Basin record.

\section{Comparison to G. ruber (pink) $\mathrm{Mg} / \mathrm{Ca}-\mathrm{SST}$}

[44] Orca Basin G. ruber (pink) $\mathrm{Mg} / \mathrm{Ca}-\mathrm{SST}$ also exhibits millennial-scale variability during the last deglaciation (Figure 4). The G. ruber (pink) record displays a $3.0 \pm$ $0.6^{\circ} \mathrm{C}$ increase in SST from the early deglacial period (mean $=23.0^{\circ} \mathrm{C}$ from 18.4 to $17.8 \mathrm{ka}$ ) to the early Holocene $\left(\right.$ mean $=26.1^{\circ} \mathrm{C}$ from 11.5 to $\left.10.8 \mathrm{ka}\right)$. An early SST increase is seen at $\sim 17.8-16.3 \mathrm{ka}\left(\sim 2.2 \pm 0.5^{\circ} \mathrm{C}\right)$ followed by a plateau from 16.3 to $14.7 \mathrm{ka}$ with mean values of $25.3^{\circ} \mathrm{C}$. At $\sim 14.8 \mathrm{ka} \mathrm{SSTs}$ increase slightly to maximum values of $\sim 26.4^{\circ} \mathrm{C}$. From approximately $14.7-14.2 \mathrm{ka}$ G. ruber (pink) SST decreases $1.4 \pm 0.7^{\circ} \mathrm{C}$ (based on the difference in mean values from 14.8 to $14.7 \mathrm{ka}$ and $14.2-14.0$ $\mathrm{ka})$. SSTs then increase from 14.1 to $13.7 \mathrm{ka}$ and plateau to $\sim 25.3^{\circ} \mathrm{C}$ from 13.7 to $12.9 \mathrm{ka}$ with a one rapid excursion from $\sim 13.5-13.35 \mathrm{ka}$ to lower values $\left(24.0^{\circ} \mathrm{C}\right)$.

[45] When compared to the G. ruber (white) SST record, the pink variety records warmer SSTs; however the offset is not constant throughout the entire deglacial sequence. Indeed, the two SST reconstructions appear to be anticorrelated for the majority of the deglacial interval with the exception of the $3.0^{\circ} \mathrm{C}$ increase during early deglacial period that coincides with a $4.6^{\circ} \mathrm{C}$ warming in the G. ruber (white) record. For example, during the Oldest Dryas interval, G. ruber (white) SST exhibits a sustained cooling while the $G$. ruber (pink) SST plateaus at warmer temperatures.

[46] Furthermore, the G. ruber (pink) $\mathrm{Mg} / \mathrm{Ca}-\mathrm{SST}$ record exhibits some similarities to Antarctic air temperature reconstructions (Figure 4). At the onset of the Bolling-Allerod, the pink variety displays an initial cooling of $1.4 \pm 0.7^{\circ} \mathrm{C}$ as Antarctica temperatures plateau. However, G. ruber (pink) SSTs display an increase during the Bolling-Allerod at approximately $14.1-13.6 \mathrm{ka}$, which is not seen in the Antarctic record. During the Younger Dryas, the G. ruber (pink) SST record exhibits a two-part interval. While G. ruber (white) SSTs decrease by $\sim 2.4^{\circ} \mathrm{C}$, G. ruber (pink) SSTs decrease initially by $0.8 \pm 0.4^{\circ} \mathrm{C}$ from 12.9 to $12.4 \mathrm{ka}$ but are followed by a $1.4 \pm 0.5^{\circ} \mathrm{C} \mathrm{SST}$ warming throughout the remaining interval which is also seen in Antarctic air temperatures.

[47] The correlation of G. ruber (white) SST to Greenland air temperatures and G. ruber (pink) SST to Antarctica, respectively, suggests that Orca Basin climate may be linked to both Northern and Southern Hemisphere climate change during the last deglaciation. One hypothesis is that Greenland stadials, which most strongly affect North Atlantic winter conditions, are also being recorded in the G. ruber (white) SST. As this variety is likely present year-round in the GOM, its signal may be more strongly recording winter conditions than the G. ruber (pink). If the pink variety is not present in the GOM during stadial winters, its SST signal would represent a summer-weighted record. Therefore, divergences between the two records might be used to infer changes in seasonality. Alternatively, if the G. ruber (pink) represents a slightly deeper SST signal than the G. ruber (white), then SST divergences may reflect 
changes in the position and strength of the seasonal thermocline. However, because the G. ruber (pink) SST record records warmer temperatures than the $G$. ruber (white), it is unlikely that it is living at deeper depths.

[48] As previous research suggests, Greenland stadials may have been intervals of enhanced seasonality (within the northern North Atlantic region) marked by extremely cold boreal winter conditions related to extensive winter sea-ice formation [Denton et al., 2005; Broecker, 2006]. With the working hypothesis that variations between $G$. ruber (white and pink) SST are due to different seasonal preferences, we suggest that enhanced seasonality during the last deglacial sequence also extended into the northern GOM. Because $G$. ruber (white and pink) SST trends diverge during the Oldest Dryas, and the Younger Dryas intervals, seasonality appears to be enhanced at these times and decreased during the Bolling-Allerod (Figure 4). Our new G. ruber $\mathrm{Mg} / \mathrm{Ca}-\mathrm{SST}$ results also provide support for Ziegler et al.'s [2008] suggestion of enhanced seasonality during the Oldest and Younger Dryas in the AWP based on the DeSoto Canyon core.

\section{Conclusions}

[49] G. ruber (white) $\mathrm{Mg} / \mathrm{Ca}-\mathrm{SST}$ data from the Orca Basin with excellent ${ }^{14} \mathrm{C}$ age control, exhibit a $5.6 \pm 0.6^{\circ} \mathrm{C}$ early deglacial to early Holocene SST increase with distinct coolings at $16.0-14.7 \mathrm{ka}\left(1.0 \pm 0.5^{\circ} \mathrm{C}\right)$ and $12.8-11.6 \mathrm{ka}$ $\left(2.4 \pm 0.6^{\circ} \mathrm{C}\right)$ during the Oldest and Younger Dryas. The onset of the Bolling-Allerod warm period displays a $2.7 \pm$ $0.6^{\circ} \mathrm{C}$ SST increase. Our results are the first to confirm the Oldest Dryas, Bolling-Allerod and Younger Dryas in the GOM based on $\mathrm{Mg} / \mathrm{Ca}-\mathrm{SST}$, indicating rapid climate changes affecting the North Atlantic region also influence subtropical climate. These large temperature changes are not seen in a DeSoto Canyon core due to the inferred presence of the Loop Current which created a distinctly separate climate region in the northeastern GOM [Nürnberg et al., 2008].

\section{References}

Anand, P., H. Elderfield, and M. H. Conte (2003), Calibration of $\mathrm{Mg} / \mathrm{Ca}$ thermometry in planktonic foraminifera from a sediment trap time series, Paleoceanography, 18(2), 1050, doi:10.1029/2002PA000846.

Bard, E., F. Rostek, J.-L. Turon, and S. Gendreau (2000), Hydrological impact of Heinrich events into the subtropical northeast Atlantic, Science, 289, 1321-1324, doi:10.1126/ science.289.5483.1321.

Barker, S., M. Greaves, and H. Elderfield (2003), A study of cleaning procedures used for foraminiferal $\mathrm{Mg} / \mathrm{Ca}$ paleothermometry, Geochem. Geophys. Geosyst., 4(9), 8407, doi:10.1029/ 2003GC000559

Barrows, T. T., S. J. Lehman, L. K. Fifield, and P. De Deckker (2007), Absence of cooling in New Zealand and the adjacent ocean during the Younger Dryas Chronozone, Science, 318, 86-89, doi:10.1126/science. 1145873.

Bé, A. W. H. (1959), Ecology of recent planktonic foraminifera. Part 1: Areal distribution in the western North Atlantic, Micropaleontology, 5, 77-100, doi:10.2307/1484157.
[50] G. ruber (pink) Mg/Ca-SST is often not in phase with G. ruber (white) $\mathrm{Mg} / \mathrm{Ca}-\mathrm{SST}$ and is similar to Antarctic air temperature reconstructions. As G. ruber (white and pink) may prefer different seasons, divergent SST trends during Greenland stadials suggest changes in northern GOM seasonality during the deglacial sequence, consistent with northern North Atlantic observations. G. ruber (pink) exhibits a modest cooling trend of $1.4 \pm 0.7^{\circ} \mathrm{C}$ during the Bolling-Allerod, an interval of strong THC. We have no ready explanation for $G$. ruber (pink) SST cooling during the Bolling-Allerod.

[51] Both G. ruber (white and pink) $\mathrm{Mg} / \mathrm{Ca}-\mathrm{SST}$ records exhibit a large SST increase before the onset of the BollingAllerod $\left(4.6 \pm 0.6^{\circ} \mathrm{C}\right.$ and $2.2 \pm 0.6^{\circ} \mathrm{C}$, respectively), synchronous with changes in Northern Hemisphere summer insolation [Laskar et al., 2004] and the $\mathrm{Pa} / \mathrm{Th}$ proxy for THC strength [McManus et al., 2004]. Together with the DeSoto Canyon and Tobago Basin SST records, these data suggest that early warming was fundamentally driven by a combination of increased local insolation and low-latitude heat storage associated with NADW reduction. The lack of clear SST warming during the Younger Dryas based on our new Orca Basin G. ruber (white and pink) and previously published Desoto Canyon $\mathrm{Mg} / \mathrm{Ca}-\mathrm{SS}$ records [Nürnberg et al., 2008] do not support heat buildup during a second interval of reduced THC.

[52] Acknowledgments. We thank the IMAGES program, Viviane Bout-Roumazeilles, Yvon Balut, and Laurent Labeyrie for a productive cruise on the R/V Marion Dufresne in 2002. This work was supported by the Gary Comer Science and Education Foundation (CP-18 to B.P.F. and D.W.H.), with partial support from the National Science Foundation under grants OCE-0318361 and OCE-0903017. Radiocarbon analyses were performed under the auspices of the U.S. Department of Energy by Lawrence Livermore National Laboratory (contract W-7405-Eng-48). We also thank Jessica Spear, Julie Richey, and USF Paleo lab members for useful discussions and Eckerd College interns Hilary Browning, Kaela Wuestoff, Katie Slatterey, and Missy Gilbert for help in sample preparation. We thank Rainer Zahn, Stefan Mulitza, and an anonymous reviewer for insightful reviews.
Bé, A. W. H. (1960), Ecology of recent planktonic foraminifera. Part 2: Bathymetric and seasonal distributions in the Sargasso Sea off Bermuda, Micropaleontology, 6, 373-392, doi: $10.2307 / 1484218$.

Bé, A. W. H. (1982), Biology of planktonic foraminifera, in Foraminifera: Notes for a Short Course, Stud. Geol., vol. 6, edited by T. W. Broadhead, pp. 51-89, Univ. of Tenn., Knoxville.

Bé, A. W. H., and W. H. Hamlin (1967), Ecology of recent planktonic foraminifera. Part 3: Distribution in the North Atlantic during the summer of 1962, Micropaleontology, 13, 87106, doi:10.2307/1484808.

Bemis, B. E., H. J. Spero, J. Bijma, and D. W. Lea (1998), Reevaluation of the oxygen isotopic composition of planktonic foraminifera: Experimental results and revised paleotemperature equations, Paleoceanography, 13 , 150-160, doi:10.1029/98PA00070.

Bijma, J., W. W. Faber, and C. Hemleben (1990), Temperature and salinity limits for growth and survival of some planktonic forami- nifers in laboratory cultures, J. Foraminiferal Res., 20, 95-116, doi:10.2113/gsjfr.20.2.95.

Björck, S., et al. (1996), Synchronized terrestrialatmospheric deglacial records around the North Atlantic, Science, 274, 1155-1160, doi:10.1126/science.274.5290.1155.

Björck, S., M. J. C. Walker, L. C. Cwynar, S. Johnsen, K.-L. Knudsen, J. J. Lowe, and B. Wohlfarth (1998), An event stratigraphy for the Last Termination in the North Atlantic region based on the Greenland ice-core record: A proposal by the INTIMATE group, J. Quat. Sci., 13, 283-292, doi:10.1002/ (SICI)1099-1417(199807/08)13:4<283::AIDJQS386>3.0.CO;2-A

Blunier, T., and E. J. Brook (2001), Timing of millennial-scale climate change in Antarctica and Greenland during the last glacial period, Science, 291, 109-112, doi:10.1126/ science.291.5501.109.

Blunier, T., J. Schwander, B. Stauffer, T. Stocker, A. Dällenbach, A. Indermühle, J. Tschumi, J. Chappellaz, D. Raynaud, and J.-M. Barnola (1997), Timing of the Antarctic cold reversal 
and the atmospheric $\mathrm{CO}_{2}$ increase with respect to the Younger Dryas event, Geophys. Res. Lett., 24, 2683-2686, doi:10.1029/ 97GL02658.

Brauer, A., C. Endres, C. Günter, T. Litt, M. Stebich, and J. F. W. Negendank (1999), High resolution sediment and vegetation responses to Younger Dryas climate change in varved lake sediments from Meerfelder Maar, Germany, Quat. Sci. Rev., 18, 321-329, doi:10.1016/S0277-3791(98)00084-5.

Brauer, A., G. H. Haug, P. Dulski, D. M. Sigman, and J. F. W. Negendank (2008), An abrupt wind shift in western Europe at the onset of the Younger Dryas cold period, Nat. Geosci., 1, 520-523, doi:10.1038/ngeo263.

Broecker, W. S. (1998), Paleocean circulation during the last deglaciation: A bipolar seesaw?, Paleoceanography, 13, 119-121, doi:10.1029/97PA03707.

Broecker, W. S. (2006), Abrupt climate change revisited, Global Planet. Change, 54, 211-215, doi:10.1016/j.gloplacha.2006.06.019.

Broecker, W. S., M. Andree, W. Wolfli, H. Oeschger, G. Bonani, J. Kennett, and D. Peteet (1988), The chronology of the last deglaciation: Implications to the cause of the Younger Dryas event, Paleoceanography, 3, 1-19, doi:10.1029/PA003i001p00001.

Crowley, T. J. (1992), North Atlantic Deep Water cools the Southern Hemisphere, Paleoceanography, 7, 489-497, doi:10.1029/92PA01058.

Demske, D., G. Heumann, W. Granoszewski, M. Nita, K. Mamakowa, P. E. Tarasov, and H. Oberhänsli (2005), Late glacial and Holocene vegetation and regional climate variability evidenced in high-resolution pollen records from Lake Baikal, Global Planet. Change, 46, 255-279, doi:10.1016/ j.gloplacha.2004.09.020

Denton, G. H., R. B. Alley, G. C. Comer, and W. S. Broecker (2005), The role of seasonality in abrupt climate change, Quat. Sci. Rev., 24, 1159-1182, doi:10.1016/j.quascirev.2004.12.002.

Ebbesen, H., and M. Hald (2004), Unstable Younger Dryas climate in the northeast North Atlantic, Geology, 32, 673-676, doi:10.1130/ G20653.1.

EPICA Community Members et al. (2006), Oneto-one coupling of glacial climate variability in Greenland and Antarctica, Nature, 444, 195-198, doi:10.1038/nature05301.

Ferguson, J. E., G. M. Henderson, M. Kucera, and R. E. M. Rickaby (2008), Systematic change of foraminiferal $\mathrm{Mg} / \mathrm{Ca}$ ratios across a strong salinity gradient, Earth Planet. Sci. Lett., 265, 153-166, doi:10.1016/j.eps1.2007.10.011.

Flower, B. P., and J. P. Kennett (1990), The Younger Dryas cool episode in the Gulf of Mexico, Paleoceanography, 5, 949-961, doi:10.1029/PA005i006p00949.

Flower, B. P., D. W. Hastings, H. W. Hill, and T. M. Quinn (2004), Phasing of deglacial warming and Laurentide Ice Sheet meltwater in the Gulf of Mexico, Geology, 32, 597-600, doi:10.1130/G20604.1.

Greaves, M., et al. (2008), Interlaboratory comparison study of calibration standards for foraminiferal $\mathrm{Mg} / \mathrm{Ca}$ thermometry, Geochem. Geophys. Geosyst., 9, Q08010, doi:10.1029/ 2008GC001974.

Keigwin, L. D. (1996), The Little Ice Age and Medieval Warm Period in the Sargasso Sea, Science, 274, 1503-1508, doi:10.1126/ science.274.5292.1503
Keigwin, L. D., and E. A. Boyle (2008), Did North Atlantic overturning halt 17,000 years ago?, Paleoceanography, 23, PA1101, doi:10.1029/2007PA001500.

Kennett, J. P., K. Elmstrom, and N. Penrose (1985), The last deglaciation in Orca Basin, Gulf of Mexico: High-resolution planktonic foraminiferal changes, Palaeogeogr. Palaeoclimatol. Palaeoecol., 50, 189-216.

Kromer, B., M. Friedrich, K. A. Hughen, F. Kaiser, S. Remmele, M. Schaub, and S. Talamo (2004), Late glacial ${ }^{14} \mathrm{C}$ ages from a floating, 1382-ring pine chronology, Radiocarbon, 46, 1203-1209.

Lamy, F., J. Kaiser, U. Ninnemann, D. Hebbeln, H. W. Arz, and J. Stoner (2004), Antarctic timing of surface water changes off Chile and Patagonian ice sheet response, Science, 304, 1959-1962, doi:10.1126/science. 1097863.

Laskar, J., P. Robutel, F. Joutel, M. Gastineau, A. C. M. Correia, and B. Levrard (2004), A long-term numerical solution for the insolation quantities of the Earth, Astron Astrophys., 428, 261-285, doi:10.1051/ 0004-6361:20041335

Lea, D. W., T. A. Mashiotta, and H. J. Spero (1999), Controls on magnesium and strontium uptake in planktonic foraminifera determined by live culturing, Geochim. Cosmochim. Acta, 63, 2369-2379, doi:10.1016/S0016-7037(99) 00197-0.

Lea, D. W., D. K. Pak, L. C. Peterson, and K. A. Hughen (2003), Synchroneity of tropical and high-latitude Atlantic temperatures over the last glacial termination, Science, 301, 1361-1364, doi:10.1126/science. 1088470 .

Lea, D. W., D. K. Pak, and G. Paradis (2005), Influence of volcanic shards on foraminiferal $\mathrm{Mg} / \mathrm{Ca}$ in a core from the Galápagos region, Geochem. Geophys. Geosyst., 6, Q11P04, doi:10.1029/2005GC000970.

Leventer, A., D. F. Williams, and J. P. Kennett (1982), Dynamics of the Laurentide ice sheet during the last deglaciation: Evidence from the Gulf of Mexico, Earth Planet. Sci. Lett., 59, 11-17, doi:10.1016/0012-821X(82) 90112-1.

Levitus, S. (2003), NODC (Levitus) World Ocean Atlas 1994, http://www.esrl.noaa.gov/ $\mathrm{psd} /$ data/gridded/data.nodc.woa94.html, Natl. Oceanogr. Data Cent., Silver Spring, Md.

LoDico, J. M., B. P. Flower, and T. M. Quinn (2006), Subcentennial-scale climatic and hydrologic variability in the Gulf of Mexico during the early Holocene, Paleoceanography, 21, PA3015, doi:10.1029/2005PA001243.

Lund, D. C., and W. Curry (2006), Florida current surface temperature and salinity variability during the last millennium, Paleoceanography, 21, PA2009, doi:10.1029/2005PA001218.

Manabe, S., and R. J. Stouffer (1997), Coupled ocean-atmosphere model response to freshwater input: Comparison to Younger Dryas event, Paleoceanography, 12, 321-336, doi:10.1029/ 96PA03932.

McManus, J. F., R. Francois, J.-M. Gherardi, L. D. Keigwin, and S. Brown-Leger (2004), Collapse and rapid resumption of Atlantic meridional circulation linked to deglacial climate changes, Nature, 428, 834-837, doi:10.1038/nature02494.

Muller-Karger, F., et al. (2001), Annual cycle of primary production in the Cariaco Basin: Response to upwelling and implications for vertical export, J. Geophys. Res., 106, 4527-4542, doi:10.1029/1999JC000291.
Muscheler, R., B. Kromer, S. Björck, A. Svensson, M. Friedrich, K. F. Kaiser, and J. Southon (2008), Tree rings and ice cores reveal ${ }^{14} \mathrm{C}$ calibration uncertainties during the Younger Dryas, Nat. Geosci., 1, 263-267, doi:10.1038/ngeo128.

Nürnberg, D., J. Bijma, and C. Hemleben (1996), Assessing the reliability of magnesium in foraminiferal calcite as a proxy for water mass temperatures, Geochim. Cosmochim. Acta , 60, 803-814, doi:10.1016/0016-7037 (95)00446-7.

Nürnberg, D., M. Ziegler, C. Karas, R. Tiedemann, and M. W. Schmidt (2008), Interacting Loop Current variability and Mississippi River discharge over the past $400 \mathrm{kyr}$, Earth Planet Sci. Lett., 272, 278-289, doi:10.1016/j.eps1. 2008.04.051.

Rasmussen, S. O., et al. (2006), A new Greenland ice core chronology for the last glacial termination, J. Geophys. Res., 111, D06102, doi:10.1029/2005JD006079.

Reimer, P. J., et al. (2009), INTCAL09 and MARINE09 radiocarbon age calibration curves, 0-50,000 years cal BP, Radiocarbon, 51, 1111-1150.

Richey, J. N., R. Z. Poore, B. P. Flower, and T. M. Quinn (2007), 1400 yr multiproxy record of climate variability from the northern Gulf of Mexico, Geology, 35, 423-426, doi:10.1130/G23507A.1.

Richey, J. N., R. Z. Poore, B. P. Flower, and T. M. Quinn (2008), Reproducibility of a high-resolution, late Holocene foraminiferal $\mathrm{Mg} / \mathrm{Ca}$ record from the Gulf of Mexico, Eos Trans. $A G U, 89(53)$, Fall Meet. Suppl., Abstract PP14B-03.

Richey, J. N., R. Z. Poore, B. P. Flower, T. M. Quinn, and D. J. Hollander (2009), Regionally coherent Little Ice Age cooling in the Atlantic Warm Pool, Geophys. Res. Lett., 36 L21703, doi:10.1029/2009GL040445.

Ruddiman, W. F. (1977), Late Quaternary deposition of ice-rafted sand in the subpolar North Atlantic (lat. $40^{\circ}$ to $65^{\circ} \mathrm{N}$ ), Geol. Soc. Am. Bull., 88, 1813-1827, doi:10.1130/0016-7606 (1977)88<1813:LQDOIS > 2.0.CO;2

Rühlemann, C., S. Mulitza, P. J. Müller, G. Wefer, and R. Zahn (1999), Warming of the tropical Atlantic Ocean and slowdown of thermohaline circulation during the last deglaciation, Nature, 402, 511-514, doi:10.1038/990069.

Schmidt, M. W., H. J. Spero, and D. W. Lea (2004), Links between salinity variation in the Caribbean and North Atlantic thermohaline circulation, Nature, 428, 160-163, doi:10.1038/nature02346.

Schrag, D. P. (1999), Rapid analysis of highprecision $\mathrm{Sr} / \mathrm{Ca}$ ratios in corals and other marine carbonates, Paleoceanography, 14, 97-102, doi:10.1029/1998PA900025.

Severinghaus, J. P., and E. J. Brook (1999), Abrupt climate change at the end of the last glacial period inferred from trapped air in polar ice, Science, 286, 930-934, doi:10.1126/ science.286.5441.930.

Shiller, A. M. (1997), Dissolved trace elements in the Mississippi River: Seasonal, interannual, and decadal variability, Geochim. Cosmochim Acta, 61, 4321-4330, doi:10.1016/S0016-7037 (97)00245-7.

Stocker, T. F. (2000), Past and future reorganizations in the climate system, Quat. Sci. Rev. 19, 301-319, doi:10.1016/S0277-3791(99) 00067-0.

Tedesco, K. A., J. W. Spear, E. Tappa, and R. Z. Poore (2009), Seasonal flux and assemblage 
composition of planktic foraminifera from the northern Gulf of Mexico, U.S. Geol. Surv. Open File Rep., 2009-1293, 19 pp.

Thunell, R., E. Tappa, C. Pride, and E. Kincaid (1999), Sea-surface temperature anomalies associated with the 1997-1998 El Niño recorded in the oxygen isotope composition of planktonic foraminifera, Geology, 27, 843846, doi:10.1130/0091-7613(1999)027<0843: SSTAAW $>2.3 . \mathrm{CO} ; 2$.

Tolderlund, D. S., and A. W. H. Bé (1971), Seasonal distribution of planktonic foraminifera in the western North Atlantic, Micropaleontology, 17, 297-329, doi:10.2307/1485143.

Vellinga, M., R. A. Wood, and J. M. Gregory (2002), Processes governing the recovery of a perturbed thermohaline circulation in HadCM3, J. Clim., 15, 764-780, doi:10.1175/1520-0442 (2002) $015<0764:$ PGTROA $>2.0 . \mathrm{CO} ; 2$.
Wang, C., and D. B. Enfield (2001), The tropical Western Hemisphere warm pool, Geophys. Res. Lett., 28, 1635-1638, doi:10.1029/ 2000GL011763.

Williams, D. F., A. W. H. Bé, and R. G. Fairbanks (1981), Seasonal stable isotopic variations in living planktonic foraminifera from Bermuda plankton tows, Palaeogeogr. Palaeoclimatol. Palaeoecol., 33, 71-102, doi:10.1016/ 0031-0182(81)90033-X.

Žarić, S., B. Donner, G. Fischer, S. Mulitza, and G. Wefer (2005), Sensitivity of planktic foraminifera to sea surface temperature and export production as derived from sediment trap data, Mar. Micropaleontol., 55, 75-105, doi:10.1016/j.marmicro.2005.01.002.

Ziegler, M., D. Nürnberg, C. Karas, R. Tiedemann, and L. J. Lourens (2008), Persistent summer expansion of the Atlantic Warm Pool during gla- cial abrupt cold events, Nat. Geosci., 1, 601-605, doi:10.1038/ngeo277.

B. P. Flower, E. A. Goddard, K. A. Quinn, and C. Williams, College of Marine Science, University of South Florida, 140 7th Ave. S, St. Petersburg, FL 33701, USA. (cwilliams@ mail.usf.edu)

T. P. Guilderson, Center for Accelerator Mass Spectrometry, Lawrence Livermore Nationa Laboratory, 7000 East Ave., L-397, Livermore, CA 94551, USA.

D. W. Hastings, Collegium of Natural Sciences, Eckerd College, 4200 54th Ave. S, St. Petersburg, FL 33713, USA. 